\title{
Transatlantica
}

Revue d'études américaines. American Studies Journal

$2 \mid 2014$

Aesthetics of Theory in the Modern Era and Beyond / Photographie documentaire

\section{Anne Crémieux, Xavier Lemoine, Jean-Paul Rocchi, eds., Understanding Blackness through Performance; Contemporary Arts and the Representation of Identity}

Cécile Cottenet

\section{OpenEdition}

\section{Journals}

Édition électronique

URL : https://journals.openedition.org/transatlantica/7088

DOI : 10.4000/transatlantica.7088

ISSN : $1765-2766$

Éditeur

Association française d'Etudes Américaines (AFEA)

Référence électronique

Cécile Cottenet, « Anne Crémieux, Xavier Lemoine, Jean-Paul Rocchi, eds., Understanding Blackness through Performance; Contemporary Arts and the Representation of Identity », Transatlantica [En ligne], 2 | 2014, mis en ligne le 05 mars 2015, consulté le 06 février 2023. URL : http://journals.openedition.org/ transatlantica/7088; DOI : https://doi.org/10.4000/transatlantica.7088

Ce document a été généré automatiquement le 6 février 2023

\section{(c) (i) () $\Theta$}

Creative Commons - Attribution - Pas d'Utilisation Commerciale - Pas de Modification 4.0 International - CC BY-NC-ND 4.0

https://creativecommons.org/licenses/by-nc-nd/4.0/ 


\title{
Anne Crémieux, Xavier Lemoine, Jean-Paul Rocchi, eds., Understanding Blackness through Performance; Contemporary Arts and the Representation of Identity
}

\author{
Cécile Cottenet
}

\section{RÉFÉRENCE}

CRÉMIEUX, Anne, Xavier LEMOINE, Jean-Paul ROCCHI, eds., Understanding Blackness through Performance; Contemporary Arts and the Representation of Identity, New York, Palgrave Macmillan, 2013, 282 pages, ISBN: 978-1137325075, £ 63.00

1 Understanding Blackness through Performance is one of several publications deriving from the 2011 CAAR (Collegium for African American Research) conference organized in Paris on "Black States of Desire". Others include Black Intersectionalities; A Critique for the $21^{\text {st }}$ Century, edited by Jean-Paul Rocchi and Monica Michlin (Liverpool University Press, 2013), Black Europe: Subjects, Struggles and Shifting Perceptions (Eds. Frédéric Sylvanise and J-P. Rocchi, forthcoming from SUNY Press in 2015), and Black and Sexual Geographies of Community-Building, edited by J-P. Rocchi and Guillaume Marche (SAGE Publications, 2014, forthcoming).

In what has been termed a postracial, post-black era, this collection of essays urges us to reconsider blackness in the United States between the 1920s and today, through an intersection of inter-disciplinary approaches. The volume aims to push back, and even abolish, the boundaries of identity, and reframe blackness according to new paradigms informed by issues of race, gender, sexuality, and perhaps to a lesser extent, of class. In this perspective, performance is conceived as providing the possibility to create a space 
and time where the black body-the performing body-can " appear, disappear, mutate " (2). Just as the rigidity of racial lines and supposed fixity of identities are displaced, or destroyed, emphasizing the instability and fluidity of blackness, so are the boundaries between disciplines abolished, leaving room for genuine interdisciplinary considerations. The dialogue between individual essays is convincingly set off in the highly conceptualizing introduction that weaves connections between the four sections.

3 The thirteen essays, organized into four sections, combine cultural studies, queer theory, cinema, theatre, visual and diasporic studies, with Womanist theory, autoethnographic writing, and trauma theory. Spanning a period between the $1920 \mathrm{~s}$ and the 2010s, the contributions construe performance in several ways and envisage different expressions: from stage performances, be it in church or on a runway (Gayle Baldwin), on the vaudeville stage in the cases of Josephine Baker and Adelaide Hall (Zakiya R. Adair), or in documentary theatre (Xavier Lemoine on Anna Deavere Smith); to the visual arts, with a specific focus on film (Anne Crémieux, Simon Dickel and Rinaldo Walcott), on sculpture (James Smalls on Richmond Barthé), or "print", in Vanina Géré's exploration of Kara Walker's silhouettes. The first, and perhaps most challenging section, considers "writing as performance", as it brings together three contributions sharing an autoethnographic approach, underscoring individual experiences of academic selves.

4 The first section requires a shift in perspective from the reader, perhaps an even greater redirecting of gaze on the part of French academics not yet familiarized with reflexive scholarly writing. Indeed, unabashedly political, these first three essays challenge standard academic writing in several ways. Grounded in autoethnography (Milton Beasley) and Womanist rhetoric (Toneisha L. Taylor and Gayle Baldwin), they foreground the importance of self- or (dis)narratives as means of healing, or spiritual salvation. Positing the authenticity of one's voice, and of black women's voices, they engage with self-reflexive narratives to question the position of the academic writer within his/ her community, and towards his/her "fieldwork"-in the case of Taylor and Baldwin, observation of LGBTQ communities. The latter, writings of academics and activists, help to place sexual minorities back on the academic map: while Baldwin develops a parallel between performance in the black church and a Drag Ball, Taylor asks whether Womanist rhetoric might not include Drag queens, so as to help littleheard voices to emerge. Tackling the question of the voices of identities not normed by dominant discourse, Taylor and Baldwin raise the question of authenticity, a central issue in Womanist theory, and cogently, address the issue of legitimacy: who may enter the conversation on Black drag queens? From where? To these questions, aware that her white gaze might be perceived as voyeuristic, Gayle Baldwin replies that being lesbian endows her with a unique perspective, as it provides both a "common denominator" with Queer Black men, and sharpens her awareness of racism. Although this section does not entirely avoid a certain overshadowing of the object by the reflexive discourse, calling for critical participatory observation, it forces the reader to acknowledge his/her own positioning towards the issue of black gendered identity.

The gaze of the onlooker, his/her distance and responsibility in perpetuating racist or sexist stereotypes are central to the four essays in the second section. They all, to some extent, question problematic representations of blackness bordering on stereotypes and even-in the case of artist Kara Walker's silhouettes (Vanina Géré) and Lee Daniels's 
adaptation of Sapphire's novel Push (A. Crémieux)-criticized for reiterating racist tropes. A. Crémieux, V. Géré and Z. Adair specifically posit the centrality of the onlooker in conceiving and defining blackness. Building on an analysis of Josephine Baker's and Adelaide Hall's dancing performances and their transatlantic reception, Adair's essay demonstrates that these black women performers were able to transcend the primitive/modern dichotomy generally associated with constructions of blackness in the 1920s and 1930s. Playing on fantasies and colonial projections of African and African Americans, Baker was thus able to resist being constrained by said projections, and to achieve in France an autonomy that she was not granted in the United States. In very much the same way, through close film analysis, Anne Crémieux demonstrates how the film adaptation of Sapphire's Push ultimately escapes a dangerous caricaturing of blackness-identified here with poverty, illiteracy, and incest. Her contribution, which opens with a list of all the social and racial stereotypes abounding in both book and film, shows that the movie's performance, as well as that of the actress playing the part of Precious, allow the viewer to identify with the young illiterate teenage mother, and to reinvest her body with positive elements. Blackness is thus performed - against all odds, positively-by the onlooker. Such is also the case with Kara Walker's silhouettes, as V. Géré convincingly argues. Just like Sapphire, Walker has been the object of a controversy regarding her representations of blackness, whose excessive violence has often been seen as evocative of the most racist imagery. For Géré the violence in Walker's art serves a strategy aimed at fostering individual change, provided viewers take the time to ponder what they see, interpret and question their own positions towards race, gender and class. As Géré writes,

Stereotypes of blackness and whiteness are thus exposed as mental projections; caricatures, as grotesque fictions that were actually already within ourselves when we started looking [...]. Walker's pictures are the site of unbearable violence not only in terms of contents, but also inasmuch as Walker partly lays the responsibility of such contents onto the viewer, arousing feelings of unease, guilt, and shame within us [...]. (98)

6 As for Simon Dickel's essay, it also purports to show how blackness may be explored and problematized, if not so much redefined, from a post-black or post-soul perspective. As the title of this second section "Shattered Frames and the Onlooker: Strategies and Significations"-suggests, Dickel shatters the 1960s-1970s activist framework of analysis to view blackness as inherently multiple and flexible. Through his analysis of Barry Jenkins's hybrid film Medicine for Melancholy (2008), he demonstrates how representations of black identity are informed by a crossing of lines: racial, cultural, and genre, since the film both qualifies as "mumblecore", a quintessentially white film genre, and signifies on earlier Afro British cinema as exemplified by the intertext with Menelik Shabazz's 1981 cult classic Burning an Illusion. Dickel further conjures up the diasporic perspective to theorize blackness "beyond the national frame of African American identity" (115), much in the way of Josephine Baker's transnational representations of blackness.

7 If writing as performance was the focus of the first section, the third section centers on the black performing body, a locus of desire, and, according to the introduction, "both a prison and a source of freedom [...] a pharmakon" (12), depending on the constructions, projections and desire of the onlooker. The dying body is at the center of the eighth chapter, where death is considered as an instrument to probe blackness in 
new and less restrictive, and restricted, ways. Focusing on a "black queer imagearchive", notably Marlon Riggs' films and the photographs of Nigerian-born artist Rotimi Fani-Kayode and American Lyle Ashton Harris, Rinaldo Walcott develops a diasporic studies approach, and envisages an intimate, inescapable link between death and black diasporic identity, a connection inaugurated by the experience of the Middle Passage. Walcott, who contributed to the seminal 2005 Black Queer Studies: A Critical Anthology, co-edited by Mae G. Henderson whose essay follows, was among the first to point out the necessary connections between diaspora studies and black queer studies. Taking his cue from Edouard Glissant, he builds on the concept of " homopoetics "defined as "the practice and analysis of how black queers relate (or not) with other queers all the while producing modes of being that are both in concert with and against hegemonic gay and lesbian identities, homonormative inclusion, and black homophobia" (147)-, contending that the visual works of these black queer artists participate in the homopoetic relations "across the black diaspora " (147). He ultimately questions whether death might not define, or at least contribute to defining, black queerness.

Grounded in cultural studies, the next two essays tackle discriminations inherent to the black hip hop subculture, to show how the black performing body functions, indeed, as a pharmakon: to some extent dialoguing with Adair's contribution on black vaudeville, Mae G. Henderson presents a convincing and entertaining study of the black female body as both inscribing vulnerability and as a place of empowerment, through the case of "video vixens"; Stephany Spaulding, using a classic center/ margin dichotomy combined with the frontier theories of Gloria Anzaldua, focuses on hip hop producers' articulation or rejection of queer. Cultural Studies have long debated, and continue to discuss, the dual nature of hip hop, which is both a commodified/commercial and a counter-hegemonic subculture. Spaulding underlines the fact that, in spite of the prevailing homophobia, some artists willingly choose to remain in the margins, not aspiring to the mercantile dreams of success embodied by artist Kanye West. West is here used as a foil for the "intentionally marginal" artists such as Me'shell Ndegeocello or more recently Frank Ocean, who deploy queerness not as means of setting off the hypermasculine stereotypes, but for self-affirmation as hip hop artists. In similar fashion to Gayle Baldwin in her comparison between the performances of a black church service and a New Jersey Drag ball, Spaulding sees queer as a place from which to view identity politics-both gender and race politics-freed from constraints (186). This third section again emphasizes the importance of gendered identity and gendered viewpoint in the redefining of blackness. Centering on the fetishizing of the black female body, from the Venus Hottentot, to Josephine Baker, to ultimately to hip hop video dancers, Henderson also contributes to the dialogue between gender and race studies. In entertaining fashion, she explores the central question: are "video hotties" merely playing into male-black and white-fantasies, or like Josephine Baker, do they play with these fantasies, in order to "appropriate and redirect the fetishistic gaze of the Other"(165)? If the first parts of the contribution are convincing, the last sectionan afterthought?-is perhaps debatable, or would at least warrant an expanded development: Henderson suggests that recent trauma theories (Shoshana Felman) and the 1980 DSM (Diagnostic and Statistical Manual of Mental Disorders) classification of PTD, or "post-traumatic slave disorder", might be useful to view the performances of video "hotties" not so much in terms of dominance/ resistance, but as reenactments of 
past abuses, and their bodies, as performing a traumatic history (174). Does this not too swiftly do away with responsibility?

The final section, entitled "Shifting Paradigms of Identities," reasserts the necessity and the possibility for performance to open a space and a time for freed, unconstrained black identities, all the while pointing out the very limits that continue to be used in the defining of blackness. James Smalls' study of sculptor Richmond Barthé shows how his creative freedom was embodied in two of his male nudes, "Féral Benga" (1935) and "Stevedore" (1937) created during the Harlem Renaissance, which ultimately "transgressed racial and sexual boundaries" (209), in part through a fluidity of lines. Yet, the exclusion of homosexuality on the part of many artists and leaders of the Harlem Renaissance, some of whom-including Alain Locke-were in fact closeted homosexuals, prevented Barthé from fully escaping his own "prison", resulting in his entrapment in his own internal conflicts informed by his racial, sexual, and religious identities. In the line of previous essays, this contribution suggests that a closer focus on homoerotic desire in the works of the Harlem Renaissance might help to reevaluate the "mechanics of race identities". As he complicates blackness, Smalls also critiques the New Negro ideology, which contributed to the rigidifying of racial lines as it saw "the self and 'the race'" as a "unified, legible, and coherent construction" (203).

The next chapter brings us from New Negro to postblackness...at the other end of the spectrum Percival Everett's anti-race man in I Am Not Sidney Poitier (2009) articulates the difficulty of being defined in reductive terms, and contrary to one's self-definition. This novel is an especially good choice for a reflection on blackness, as it truly poses the question of what it means to be "black... enough". Some of the issues broached by Kristin Leigh Moriah are actually part and parcel of the debate on hip hop/gangsta lit'how does one "market" one's race identity? To what extent should Everett's protagonist play to publishers' lust for lucrative racial stereotypes such as abound today in street literature? Her analysis actually enters into dialogue with several other contributions, including Crémieux's, as Everett signifies on the controversy around the publication of Sapphire's Push, and Henderson's articulation of the problematics of hip hop. While Henderson examined the stereotypes attached to the black female body, Everett revisits black masculinity in the 2000s, albeit not so much through queer theory. The only contribution written from a literary perspective, Moriah's is particularly enlightening on the concepts and frameworks of post-soul, post-race, and post-blackness. Indeed, she convincingly demonstrates how the protagonist, Not Sidney Poitier, embodies the contradictions of post-blackness; as she claims, "The irony of this cultural moment is that while post-blackness calls for expansion and unburdening, American culture at large neither recognizes nor rewards such efforts" (224). For Moriah, in spite of the post-race/ post-black discourse, Everett's novel actually emphasizes the "inescapability of racialized performance" (224).

11 Following from this rather pessimist take, Xavier Lemoine's contribution closes the volume on a more hopeful note, forcefully substantiating the transformative potentiality of performance-here, documentary drama. In the wake of the 1991 and 1992 New York and Los Angeles race riots, Anna Deavere Smith created two pieces from interviews she conducted with individuals who had either witnessed, or were reacting to, the events. She then performed these reactions alone on stage. Lemoine examines how, through this process, Smith's body and acting methods provided the wished-for space and time where identity/ies may become fluid again. With this final essay, the 
volume shifts from autoethnography to ethnology... Just as the (dis)narratives contemplated in the first section were intended to bring about a voice of one's own as well as a form of spiritual salvation, Deavere Smith's performed narratives both raise consciousness and allow one to address traumatic experiences.

Conclusion:

This volume of essays testifies to the richness of current debates on blackness, as illustrated by the postsoul/postblack aesthetics and thinking which may allow for "expanded dialogues about race", "invigorating debates about the necessity of collapsing racial binary while remaining sensitive to the remaining realities of racial prejudice" (222). To echo Toneisha L. Taylor's words, where, and how, we enter this conversation on identity, does matter, yet this should not be a substitute for actual discussion. As Black Arts and identity politics of the 1960s-1970s are being "shattered" and the postblack era ushered in, this volume confirms that intersectional approachesdiasporic studies and especially queer theory, which owes much to earlier race and ethnic studies-have, since the late 1990s, done much for the analysis of the representation of identity. Such cross-pollination of disciplines contributes to the displacing of race discourse away from a single focus on oppression versus resistance. As Michael Eric Dyson states in his introduction to Touré's Who's Afraid of Post-Blackness? What it Means to be Black Now, "What it means to be Black will always be richer than our response to oppression at any point in our history" (2011, xvi). By complicating blackness, these essays perform a veritable service, not only for scholars in African American studies, but for anyone willing to probe identity in our "post-racial" age.

\section{AUTEURS}

CÉCILE COTTENET

Aix-Marseille Université 